\title{
ZANIKNUTÉ STAVBY V AREÁLI FARSKÉHO KOSTOLA VO SVÄTOM JURE (VÝSLEDKY GEOFYZIKÁLNEHO A ARCHÍVNEHO VÝSKUMU)
}

\author{
RASTISLAV LUZ - ROMAN PAŠTEKA - DAVID KUŠNIRÁK - BARBORA ŠIMONOVÁ
}

\begin{abstract}
Abstrakt: Štúdia predstavuje výsledky geofyzikálneho výskumu realizovaného v opevnenom areáli Kostola sv. Juraja vo Svätom Jure a na neho nadväzujúceho archivneho výskumu. Geofyzikálne merania prebiehali v juhovýchodnej časti areálu. Na preskúmanom úseku boli objavené zvyšky troch výrazných objektov. Jeden $z$ nich bol na základe archivneho výskumu identifikovaný ako pozostatky stredovekej Kaplnky sv. Barbory, ktorá bola zbúraná v roku 1798. Zo stavby sa okrem zvyškov múrov zachovala aj krypta väčsich rozmerov. D̆alšie dva objekty (jeden kruhového a jeden pravouhlého pôdorysu) sa varchivnych prameňoch nepodarilo identifikovat'. Okrem toho boli na skúmanej ploche zistené nepravidelne rozmiestnené drobné objekty, z ktorých tri pravdepodobne obsahujú kompaktné múry alebo menšie dutiny (krypty) a v dvoch pripadoch ide pravdepodobne o zvyšky múrov, ktoré ohraničujú individuálne hroby.
\end{abstract}

Kl'účové slová: Svätý Jur - sakrálna architektúra - geofyzikálny výskum - archivny výskum - stredovek.

Constructions once located in the complex of a parish church in Svätý Jur (results of a geophysical survey and archive research)

Abstract: This study presents the results of geophysical research conducted in the fortified complex of the Church of St. George in Svätý Jur and the subsequent archive research. Geophysical measurements were carried out in the south-east part of the complex. The investigated section yielded the remains of three distinct features. One of them was identified on the basis of archive research as the remains of the medieval Chapel of St. Barbara demolished in 1798. Apart from the remains of walls, a large crypt has survived. The other two features (one of a circular plan and one of a rectangular plan) were not identified in archive sources. In addition, irregularly positioned small features were detected in the observed area, three of which probably contain compact walls or hollow spaces (crypts) and in two cases possibly the remains of walls demarcating graves.

Key words: Svätý Jur - sacral architecture - geophysical survey - archive research-Middle Ages.

\section{Úvod}

Gotický Kostol sv. Juraja vo Svätom Jure sa do pozornosti odborníkov dostal už v druhej polovici 19. storočia. Záujem sa ale upriamoval zväčša len na samotnú stavbu, niektoré súčasti jej vybavenia (hlavný oltár, gotické pastofórium, náhrobníky) a prípadne aj na zvonicu stojacu samostatne vedl’a kostola, či skôr na stredoveké zvony umiestnené vo vnútri (Sabadošová 2010; Luz 2018 v oboch aj prehl’ad, resp. odkazy na staršie práce). Zvyšok areálu obohnaného kamennou hradbou zostával až na dve výnimky mimo hlavného záujmu.

Prvýkrát sa okolie kostola stalo predmetom výskumu v roku 1921 po tom, čo boli pri výkope izolačnej vzduchovej priekopy okolo kostola objavené dve steny z lomového kameňa previazané so stenou priečelia kostola. Závery následne realizovaného archeologického výskumu nepoznáme (NA, MŠ; APÚ, POS). Druhýkrát sa do areálu archeológovia vrátili v rokoch 2004-2005, ked' sa pri stavebných prácach na susednej parcele náhodne objavilo väčšie množstvo kostí. Následný archeologický výskum odkryl pozostatky murovanej kamennej stavby napojenej na severovýchodný opevňovací múr terasy kostola. V objekte pravouhlého pôdorysu s rozmermi 7,5 × 5,3 m boli uložené l'udské pozostatky, pričom išlo o zhruba 1000 jedincov. Na základe d’alšieho nájdeného materiálu bolo používanie stavby datované do 15 . až prvej polovice 17. storočia. Stavba bola identifikovaná ako dvojpodlažný karner, ktorého spodné podlažie slúžilo na uloženie kostí a vrchné ako zádušná kaplnka. Medzi kostrovými pozostatkami bol nájdený aj poklad 845 mincí (Budaj-Nagy 2005). V roku 2010 bol realizovaný geofyzikálny prieskum v interiéri kostola, $\mathrm{v}$ rámci ktorého boli detegované dve krypty a zvyšok múru v západnej časti kostola (Panisova et al. 2016). 
Počas rokov 2018 a 2019 bol realizovaný geofyzikálny a archívny výskum, ktorých primárnym ciel'om bolo lokalizovanie pozostatkov stredovekej Kaplnky sv. Barbory. Existenciu menšej sakrálnej stavby $\mathrm{v}$ areáli Kostola sv. Juraja dosvedčovali už pred začatím výskumu dva dlhšie známe pramene. Prvým z nich je veduta mesta Svätý Jur od Samuela Mikovíniho, uverejnená v práci Mateja Bela Notitia Hungariae (Bel 1736, medzi 126 a 127). Na rytine je v priestore južne od presbytéria kostola zachytená stavba zrejme kvadratického pôdorysu, ktorá vybiehala z opevňovacieho múru areálu približne juhovýchodným smerom, t. j. smerom k centru

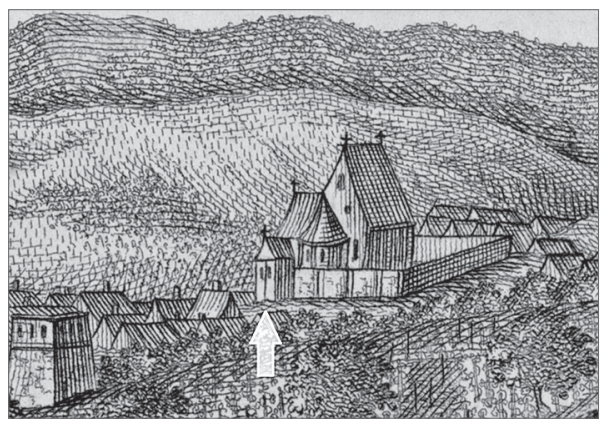

Obr. 1. Kostol sv. Juraja a jeho areál na vedute mesta Svätý Jur z roku 1736. Šípka označuje Kaplnku sv. Barbory.

Abb. 1. St. Georgskirche und ihr Areal auf einer Stadtansicht von Svätý Jur aus dem Jahr 1736. Der Pfleil kennzeichnet die St. Barbarakapelle. mesta. Stavba bola zastrešena sedlovou strechou, na ktorej bol umiestnený výrazný kríž.

Na jednej zo stien sú znázornené dve okná obdížnikového tvaru. Stredom tejto steny prechádza po celej výške zvislá čiara, ktorej význam nie je z vyobrazenia jasný. S ohl'adom na umiestnenie by mohla naznačovat' zalomenie čelnej steny, a teda polygonálne ukončenie stavby alebo aj umiestnenie oporného piliera (obr. 1 a 2). Druhým prameňom je mapa mesta Svätý Jur a jeho chotára z roku 1769 (ŠABA-Mo, ZMP). Tá v areáli kostola a v jeho blízkom okolí zakresl’uje viacero objektov, pričom väčšina z nich je aj slovne identifikovaná v legende mapy. Pod písmenom $c$ je znázornená „smrtná kaplnka“ (Todten-Capelle). Na silne schematickej mape (pôdorys kostola ani samotného areálu nie sú zakreslené verne) je pôdorys stavby zaznamenaný ako približne štvorcový, s malým polkruhovým výbežkom na južnej stene (zrejme presbytériom). Západná stena kopíruje schodisko vedúce ku kostolu (obr. 3).

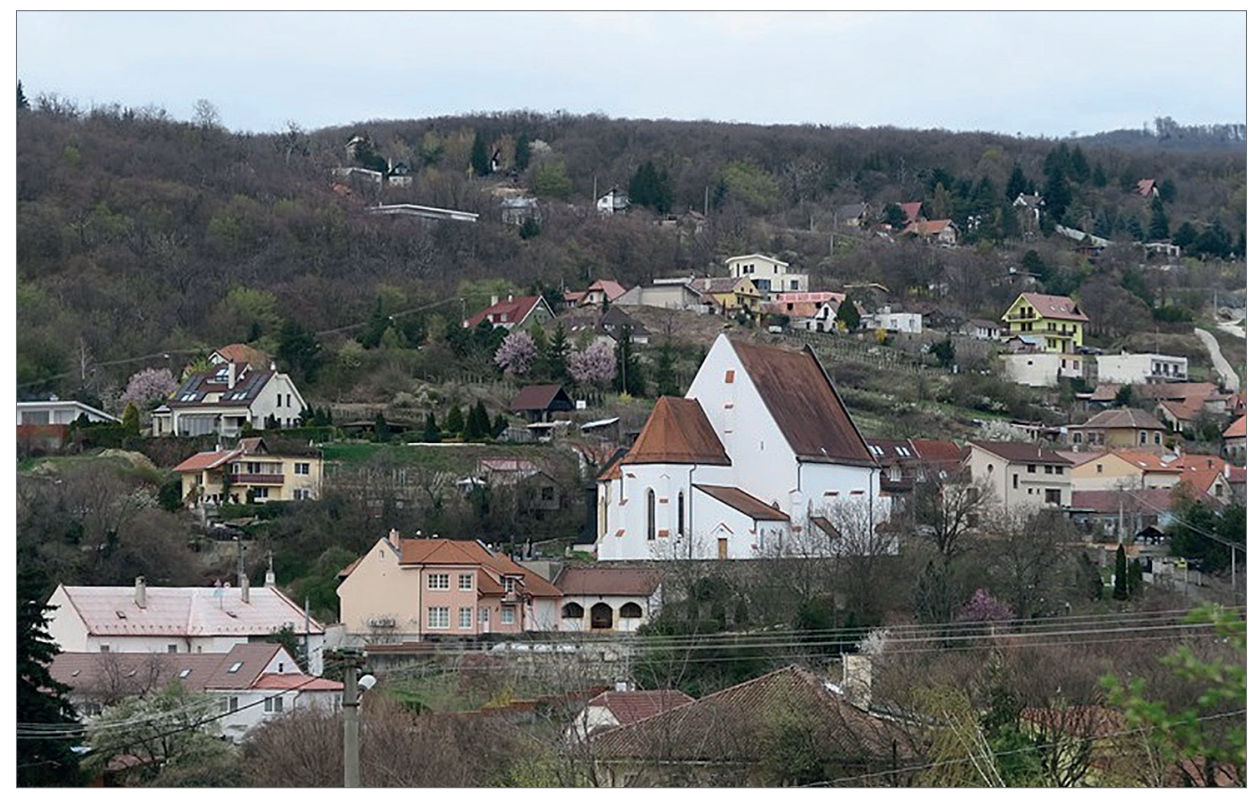

Obr. 2. Kostol sv. Juraja. Súčasný pohl’ad.

Abb. 2. St. Georgskirche. Heutige Ansicht. 


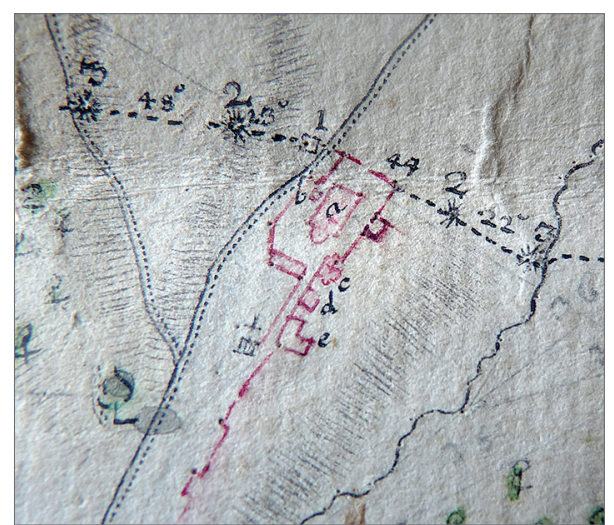

Obr. 3. Kostol sv. Juraja, jeho areál a blízke okolie na mape mesta Svätý Jur z roku 1769. a - farský kostol (Pfahr-Kirche); b - zvonica (Glocken-Thurm); c - smrtná kaplnka (Todten-Capelle); d-škola (Schule); e - fara (Pfahrherrs Wohnung). V pravej časti (bez označenia) vybiehajúci z opevnenia je zrejme karner skúmaný v rokoch 2004-2005. Mapa nie je orientovaná.

Abb. 3. St. Georgskirche, Areal der Kirche und seine nahe Umgebung auf einer Karte der Stadt Svätý Jur von 1769. a - Pfarrkirche (Pfahr-Kirche); b - Glockenturm (Glocken-Thurm); c - Totenkapelle (Todten-Capelle); d - Schule; e - Pfarrheim (Pfahrherrs Wohnung). Im rechten Teil (ohne Kennzeichnung) außen an die Umfriedungsmauer anschlieBend ist offenbar der in den Jahren 2004-2005 untersuchte Karner. Die Karte ist ohne Himmelsrichtungsangabe.
Oba opísané pramene lokalizujú stavbu na juh alebo juhovýchod kostolného areálu, do blízkosti opevňovacieho múru a vedl'a schodiska vedúceho ku kostolu. Na základe toho bola vybratá aj plocha na realizovanie geofyzikálneho výskumu. Výsledky výskumu prekonali pôvodné očakávania, pretože sa podarilo identifikovat' zvyšky až troch samostatných výrazných objektov.

\section{Geofyzikálny prieskum - metodika}

Areál farského kostola vo Svätom Jure bol v jeho juhovýchodnej časti (obr. 4) preskúmaný pomocou georadarovej metódy (bola použitá aparatúra GSSI SIR-3000 s $400 \mathrm{MHz}$ anténou) a vybraná čast' plochy aj pomocou mikrogravimetrie (bol použitý prístroj Scintrex CG-5). Kombinácia týchto dvoch metód sa používa najmä na detekciu podzemných prázdnych priestorov, ako sú väčšie hrobky a krypty (napr. Pašteka et al. 2019). Obidve použité geofyzikálne metódy boli realizované v lokálnom súradnicovom systéme, ktorý bol

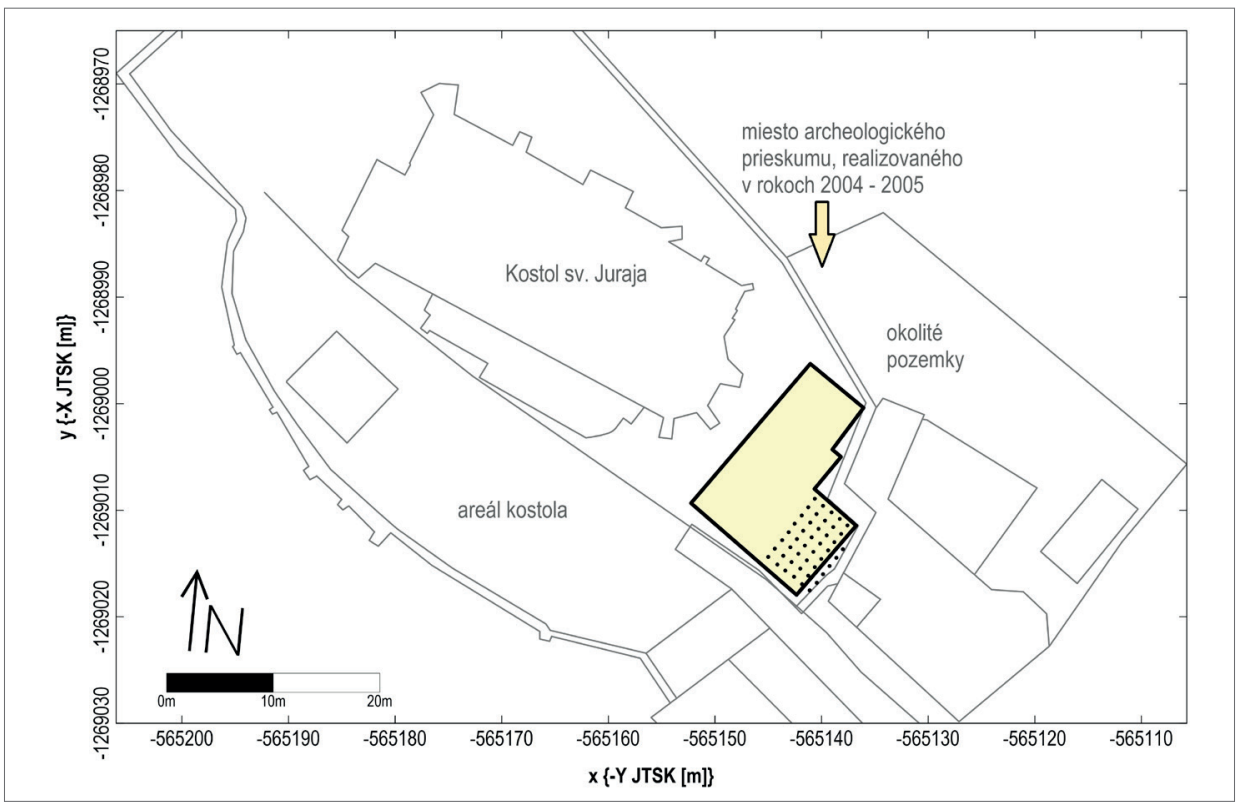

Obr. 4. Situácia geofyzikálnych meraní realizovaných počas rokov 2018-2019. Plocha ohraničená hrubou čiarou-georadarová metóda; izolované body - mikrogravimetrická metóda. Podklad tvorí katastrálna mapa Kostola sv. Juraja a jeho okolia. Zdroj ZBGIS®, Úrad geodézie, kartografie a katastra Slovenskej republiky.

Abb. 4. Situation der 2018-2019 durchgeführten geophysikalischen Messung. Mit fetter Linie umgrenzte Fläche - Georadar-Methode; isolierte Punkte - mikrogravimetrische Methode. Als Unterlage diente eine Katasterkarte der St. Georgskirche und ihrer Umgebung. Quelle ZBGIS ${ }^{\circledR}$, Amt für Geodäsie, Kartographie und Kataster der Slowakischen Republik. 
následne zameraný pomocou GNSS prístroja Trimble R8S v globálnom súradnicovom systéme JTSK-03.

V prípade georadarových meraní bola premeraná plocha nepravidelného tvaru s vel'kostou cca $175 \mathrm{~m}^{2}$ (približne $12 \times 17 \mathrm{~m}$ ). Vzdialenost' paralelných profilov bola $30 \mathrm{~cm}$ (profily prebiehali v smere JV-SZ), registrovaný časový záznam elektromagnetických impulzov bol $80 \mathrm{~ns}$, pričom každý záznam bol vzorkovaný na 1024 bodoch, čo zodpovedá vzorkovaciemu kroku 0,078 ns. Získané údaje boli spracované pomocou programu REFLEXW (Sandmeier 2019). V prvom kroku boli spracované namerané 2D vertikálne radargramy (pôvodný georadarový záznam) - najprv boli z jednotlivých radargramov odfiltrované falošné signály a šum (použitím pásmových filtrov s hranicami 200/250/550/650 MHz). Ďalej bol získaný signál zosilnený pomocou tzv. zosilňovacej
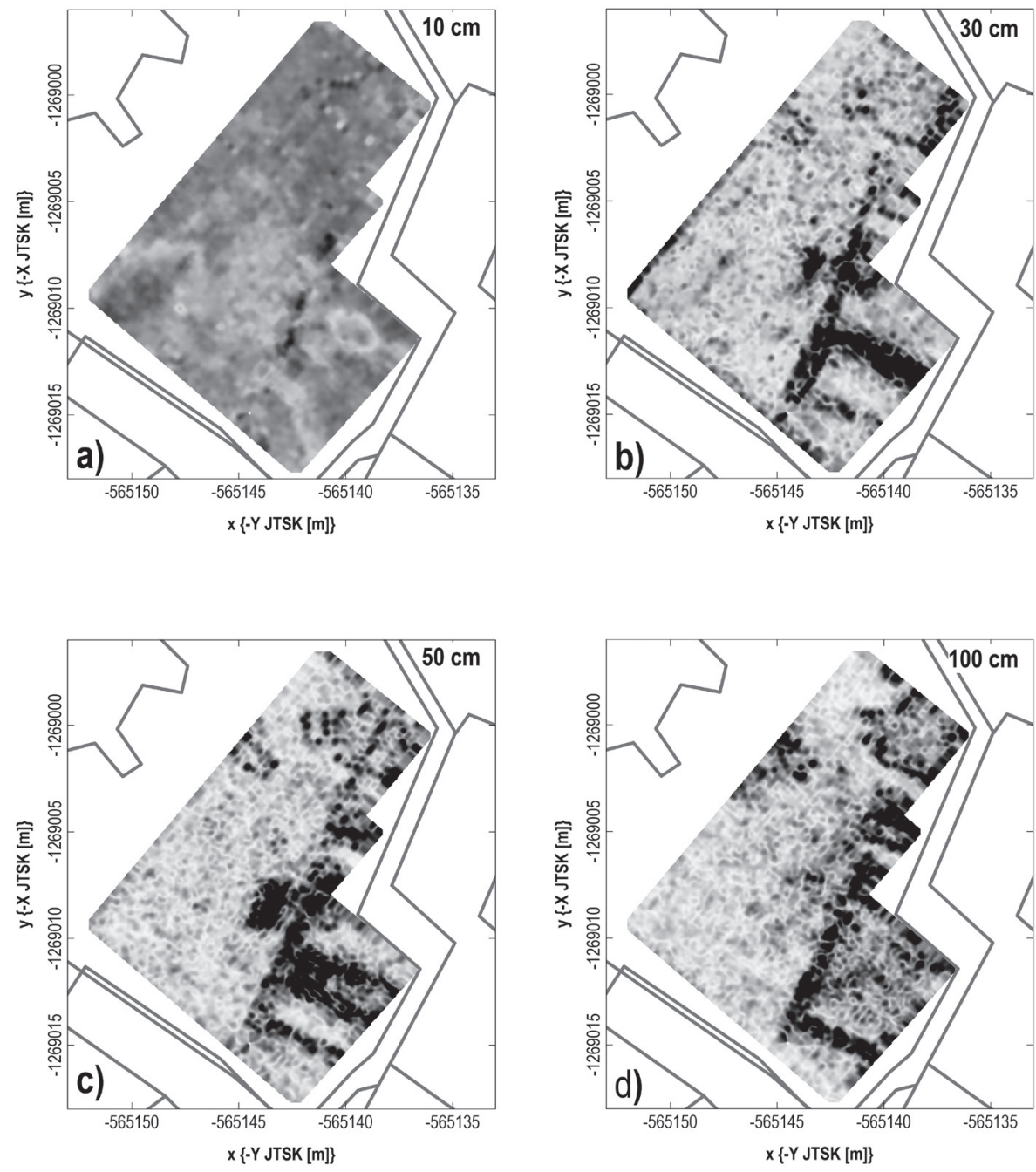

Obr. 5. Výsledok 3D spracovania získaných georadarových údajov - horizontálne amplitúdové rezy pre híbky prieniku $10 \mathrm{~cm}(\mathrm{a}), 30 \mathrm{~cm}(\mathrm{~b}), 50 \mathrm{~cm}$ (c) a $100 \mathrm{~cm}$ (d).

Abb. 5. Ergebnis der 3D-Bearbeitung der gewonnenen Georadarangaben - horizontale Amplitudenschnitte für die Eindringtiefen $10 \mathrm{~cm}(a), 30 \mathrm{~cm}($ b), $50 \mathrm{~cm}$ (c) und $100 \mathrm{~cm}(d)$. 
funkcie (gain), čím sa zvýraznil užitočný signál v záujmových oblastiach. Rýchlost’ šírenia elektromagnetických vín v pôdnom a horninovom prostredí bola určená pomocou metódy adaptácie sklonov hyperbol (hodnota $0,09 \mathrm{~m} / \mathrm{ns}$ ). Táto rýchlost' bola použitá na prepočet času príchodu impulzov na híbky jednotlivých reflexov. V druhom kroku boli výsledné spracované radargramy softvérovo spojené a vytvorili tak 3D model meraného územia. $Z$ tohto modelu boli následne vygenerované plošné mapy amplitúd vo vybraných úrovniach (tzv. horizontálne amplitúdové rezy) pre vybrané híbky $0,10 \mathrm{~m}, 0,30 \mathrm{~m}, 0,50 \mathrm{~m}, 0,75 \mathrm{~m}, 1,00 \mathrm{~m}, 1,50 \mathrm{~m}, 2,00 \mathrm{~m}, 2,50 \mathrm{~m}$ a 3,00 m (obr. 5 a 6). Na týchto mapách sú tmavšími farbami (tmavošedá až čierna) zvýraznené detegované objekty (výrazné reflektory elektromagnetického vlnenia, ako napríklad zvyšky múrov, dutiny, vyplnené výkopy, atd’.). Samotnú interpretáciu získaných georadarových výsledkov uvádzame v d’alšej kapitole.
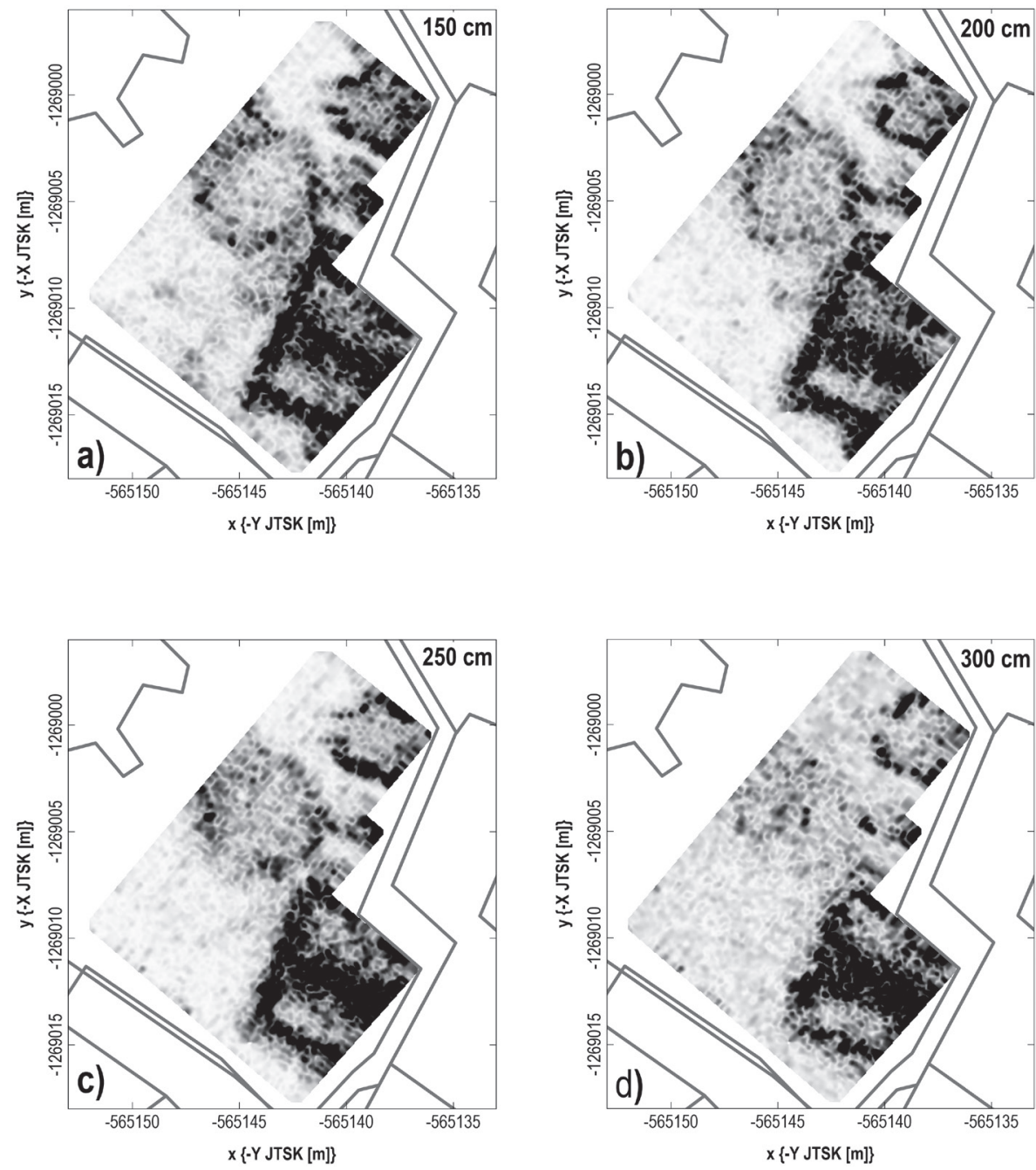

Obr. 6. Výsledok 3D spracovania získaných georadarových údajov - horizontálne amplitúdové rezy pre híbky prieniku $150 \mathrm{~cm}(\mathrm{a}), 200 \mathrm{~cm}(\mathrm{~b}), 250 \mathrm{~cm}$ (c) a $300 \mathrm{~cm}(d)$.

Abb. 6. Ergebnis der 3D-Bearbeitung der gewonnenen Georadarangaben - horizontale Amplitudenschnitte für die Eindringtiefen $150 \mathrm{~cm}$ (a), $200 \mathrm{~cm}$ (b), $250 \mathrm{~cm}$ (c) und $300 \mathrm{~cm}$ (d). 
$\mathrm{V}$ prípade mikrogravimetrických meraní bola premeraná menšia plocha - určená na základe výsledkov georadarových meraní nad detegovaným objektom I. Merania boli realizované $\mathrm{v}$ sieti bodov $1 \times 1 \mathrm{~m}$ (polohy meracích bodov sú zobrazené ako plné krúžky na obr. 7). Nadmorské výšky meraných bodov boli upresnené pomocou klasickej optickej nivelácie. Získané gravimetrické údaje boli spracované štandardným spôsobom - boli opravené o chod prístroja a prepočítané do formy tzv. neúplných Bouguerových anomálií (s použitím rovinnej Bouguerovej korekcie a korekcie na vol'ný vzduch). Tieto tiažové anomálie v sebe nesú informácie o existencii hustotných nehomogenít pod zemským povrchom (napr. Hinze-Friese-Saad 2013). Znížené hodnoty v mapách neúplných Bouguerových anomálií poukazujú na prítomnost' dutín alebo hustotne deficitných podpovrchových objektov. Získané hodnoty neúplných Bouguerových anomálií (pre korekčnú

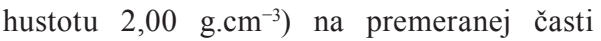
plochy sú zobrazené na obr. 7. Charakter tohto získaného anomálneho pol'a plne potvrdzuje výskyt dominantnej dutiny v priestore objektu I (výrazná negatívna anomália s amplitúdou cca $-0,035 \mathrm{mGal}$ v strede obrázku). Týmto bol potvrdený výskyt výrazne reflektujúceho objektu z georadarových meraní v tomto priestore - s najväčšou pravdepodobnostou ide o prejavy väčšej krypty.

\section{Interpretácia získaných výsledkov}

\section{Objekt I - Kaplnka sv. Barbory}

Napriek tomu, že Kostolu sv. Juraja sa vo svojich prácach venovalo viacero autorov, informácie ku kaplnke priniesol len Alexander Grósz vo svojej práci o dejinách miestneho evanjelického zboru, vydanej prvýkrát v roku 1865. Mladší autori prakticky iba preberajú jeho údaje. Grósz odkazujúc na urbár z roku 1618 píše, že vedl’a kostola stála svätyňa (Heiligthum) bez sanktuária „česká kaplnka“" s červenou tehlovou strechou. Na inom mieste bez odkazu na prameň uvádza, že kým farský kostol slúžil evanjelikom nemeckej národnosti, pre slovenských robotníkov, ktorí do mestečka prichádzali vo vel'kom počte najmä v čase prác vo vinohradoch, bola postavená Kaplnka sv. Margaréty, ktorá neskôr pod menom Kaplnka sv. Barbory stála dlhý čas opustená, až napokon bola v roku 1783 katolíckymi obyvatel'mi celkom odstránená (abgetragen wurde; Grósz s. d., 23, 43).

Počas archívneho výskumu sa podarilo nájst' väčšie množstvo prameňov, ktoré sa týkajú skúmanej stavby. Za najstaršiu zmienku o jej existencii môžeme nateraz považovat' záznamy v účtoch kostolného otca z roku 1580, v ktorých sa medzi výdavkami uvádzajú aj platby za okná, kazatel'nicu a oltár pre kaplnku, resp. ,malú kaplnku“. Ked’že účet za rok 1580 ani účet za predošlý rok 1579 (staršie účty sa nezachovali) neuvádzajú výdavky na stavebné práce na kaplnke, môžeme predpokladat', že kaplnka bola v tomto období obnovovaná, ale stavba samotná existovala už skôr. Od nasledujúceho roka 1581 sa medzi výdavkami začína pravidelne uvádzat’ aj plat „českého“ 
kazatel’a alebo farára, preto môžeme súhlasit's A. Grószom, že kaplnka bola modlitebňou slovenských veriacich (Luz 2017, 80-81).

Zmienku o slovenskom kostole (Proventus templi slavici in dem Neustiftl) uvádza aj vizitácia evanjelického superintendenta Izáka Abrahamidesa z roku 1612. Z citovaného nadpisu textu nie je jednoznačné, či kostol nesprávne lokalizuje do dediny Neštich (ležala hned' nad Kostolom sv. Juraja a od roku 1944 je súčastou mesta Svätý Jur) alebo hovorí o príjmoch kostola, ktoré mal z tejto obce. O stavbe neprináša žiadne informácie okrem tej, že kostol nemal žiadne príjmy a za jeho údržbu zodpovedalo mestečko Svätý Jur (Leška 1882, 203). O šest’ rokov neskôr zachytil podobu kaplnky už Grószovi známy urbár z roku 1618, ktorý uvádza: „Na tomto mieste majú dva kostoly. Jeden vel'ký so sanktuáriom, pokrytý škridlami a s pripojenou kaplnkou grófov zo Svätého Jura a Pezinka, nemecký, zasvätený sv. Jurajovi vojakovi a mučeníkovi, obsahujúci tiež organ. Druhý menši, slovenský (sclavonicum), tiež majúci sanktuárium, podobne červeno zastrešený “ (MNLOL, P 1391). Grósz teda zmienku o stavbe bez sanktuária uvádza nesprávne.

Na prelome rokov 1628 a 1629 museli svätojurskí evanjelici odovzdat' správu farnosti do rúk katolíkov. Kanonická vizitácia bratislavského prepošta Juraja Draškoviča z roku 1634 skonštatovala, že v celom mestečku žijú len štyria katolíci a ostatní obyvatelia sa hlásia k protestantizmu. Preto sa pochopitel'ne nepodarilo nájst' využitie pre kaplnku, o ktorej Draškovič uviedol, že „kaplnka mimo kostola na cintoríne je vždy zatvorená a prázdna“ (Beke 1994, 203). Aj pre nasledujúce obdobie sú základným prameňom kanonické vizitácie, nie všetky ale kaplnku zaznamenali. Napríklad nitriansky biskup a bratislavský prepošt Tomáš Pálfi vo svojej vizitácii z roku 1673 kaplnku opomenul, opísal len „slovenský nekatolícky kostol“, ktorý ale nie je možné stotožnit's Kaplnkou sv. Barbory, ktorá už v tom čase patrila katolíkom (ELTEK, Ab 28, 204-210). Prepošt Otto Volkra v roku 1699 uviedol, že ,na cintoríne je kaplnka zomrelých (capella defunctorum), opustená“ (ELTEK, Ab 30, 8). Vizitácia Imricha Pongráca, titulárneho biskupa diecézy Hvar a ostrihomského kanonika, z roku 1714 obsahuje podrobnejší opis a hovorí, že ,pri cintorinskych schodoch je vel'ká a pekná kaplnka, majúca pod sebou kryptu, postrádajúca však lavice, oltár a ostatné potrebné veci a čiastočne aj preto sa nevie, komu je zasvätená" (PLE, Lib 17a, 184). Možno práve Pongrácova vizitácia bola podnetom na to, aby sa stavbe po 90 rokoch chátrania začala venovat' pozornost'. V septembri 1715 bola na kaplnke urobená nová strecha, na ktorú umiestnili aj dva kríže, a zároveň bol obnovený žl'ab (canalis) medzi kaplnkou a kostolom (ŠABA, ZCM, 1090, 253). Zaujímavé informácie prináša vizitácia z roku 1731, podla ktorej bola „dost' priestranná“ kaplnka na cintoríne ponechaná opustená od roku 1491, ale v roku 1728 bola opravená Františkom Giemnerom, a bola ,ako sa hovorí“ (ut fertur) zasvätená sv. Barbore (AFSJ, Viz 1731, b. s.). Vizitátor neuviedol zdroj svojich informácií o datovaní ani o zasvätení stavby. Napriek tomu sú oba údaje takmer doslovne prevzaté vo vizitácii z roku 1756 (AFSJ, Viz 1756, 1-2) a údaj o zasvätení aj v d’alšej z roku 1761 (PLE, Lib 89, 36).

Existenciu kaplnky ako posledná zaznamenala vizitácia z roku 1781. Tzv. Batánove vizitácie z tohto obdobia sú známe svojou podrobnost'ou, vd’aka čomu sa aj v tomto prípade zachovali nielen údaje o stave stavby, ale tiež o jej rozmeroch a dokonca aj o stavebnom slohu, v ktorom bola postavená. Podl’a vizitácie bola Kaplnka sv. Barbory dlhá 5,5 siahy, široká 3 siahy a vysoká tiež 3 siahy, čo je pri prepočte s použitím bratislavskej siahy dlhej 1,9 m približne $10,45 \times 5,7 \times 5,7 \mathrm{~m}$. Kaplnka bola postavená z kameňov, zaklenutá v gotickom slohu (fornita forma gothica) a vnútri bola vydláždená. Strechu mala pokrytú škridlami, ale boli v nej mnohé a vel'ké otvory. Nemala žiadne vnútorné vybavenie a dokonca ani okná, kvôli čomu bola otvorená vetru, dažd’u a snehu. Napriek poškodeniam boli v kaplnke stále viditel'né konsekračné znaky (signa consecrationis) a kaplnka mala bránu, ktorá sa „svedomito zatvárala“. Krypta pod stavbou sa používala ako kostnica. Vizitátor poznamenal, že ak by sa do krypty urobil vchod zvonku, čo by si vyžadovalo len nevel'ké náklady, dala by sa používat' podl’a platných predpisov na pochovávanie do krýpt. Z toho môžeme usudzovat', že do krypty sa vtedy vstupovalo z interiéru. Vizitátor prikázal, aby farár v spolupráci s možnými patrónmi zabezpečil výpočet nákladov na vonkajšiu a vnútornú obnovu a zaobstaranie potrebného liturgického vybavenia, pričom obnovu mal časovo zvládnut’ tak, aby 
sa na sviatok sv. Barbory (4. decembra) nasledujúceho roku mohli v kaplnke slávit' liturgické obrady. Zároveň mal zabezpečit' aj úpravu krypty podl'a platného normatívu, aby príjem za pochovávanie v nej mohol slúžit' na d’alšiu údržbu kaplnky. Ak by ale v obnove kaplnky nenastal žiaden posun, mala sa zbúrat' a na jej mieste mala byt' vztýčená socha sv. Barbory (AFSJ, Viz 1781, 29, 233-234). Jedným $\mathrm{z}$ najdôležitejších údajov v tomto podrobnom opise je informácia o gotickom slohu, ktorý bol použitý na stavbe. Ked’že prestavba susedného farského kostola bola v roku 1590 realizovaná už v renesančnom slohu (Luz 2017, 81-82) a renesančné prvky sú doložené aj na viacerých svetských stavbách v mestečku z tohto obdobia, je to d’alší dôkaz o staršom pôvode stavby a dovol'uje datovat' kaplnku ešte do obdobia stredoveku.

Aj ked' v roku 1781 bolo nariadené zistit' možnosti opravy kaplnky, k samotným prácam sa nepristúpilo a namiesto toho bola v roku 1798 zbúraná, získaný stavebný materiál rozpredaný a utŕžené peniaze boli použité na kostolné ciele (Pavelek 1942, 36). O dva roky neskôr bola vyprataná zachovaná kostnica, podzemné priestory sa upratali a zriadila sa krypta na nové pochovávanie (Pavelek 1942, 37). Do roku 1817 (resp. 1827) je v nej doložených prinajmenšom 11 pohrebov a d'alších šest' pohrebov môžeme považovat' za pravdepodobných. Išlo o piatich (šiestich?) členov rehole piaristov, dvoch (troch?) vojenských dôstojníkov a jednu (tri?) príbuznú dôstojníka, dvoch (štyroch?) meštanov a jedného učitel’a (tab. 1). Neskoršie pohreby zaznamenané v matrikách sa už k tejto krypte priradit' nepodarilo. Podl'a odhadu z roku 1823 mala krypta postačovat' na pochovanie 30 osôb (AFSJ, Viz 1823, 28-29).

Z výsledkov realizovaných georadarových meraní je možné dobre vyčlenit' priebeh časti zvyškov základov tohto objektu (obr. 5 a 6, pravá spodná čast' premeranej plochy). Prejavujú sa dominantnými amplitúdami reflexov už od híbkovej úrovne $30 \mathrm{~cm}$ a tieto reflexy vytvárajú obdížnikový tvar, ktorý je žial' neúplný (obr. 8), nakol'ko čast' objektu, ktorá vyčnievala za opevňovací múr areálu, bola deštruovaná až po úroveň tamojšieho zníženého terénu a dnes na tomto mieste stojí rodinný dom. Dochovaná strana objektu, ktorá sa nachádza bližšie ku samotnému kostolu, má podl’a výsledkov georadaru vnútorný horizontálny rozmer približne $5,7 \mathrm{~m}$, čo je v zhode s odhadmi vypočítanými podl'a výsledkov spomenutej vizitácie z roku 1781. Vonkajší rozmer tejto strany je približne $7,5 \mathrm{~m}$. Dížku druhej strany objektu nie je možné určit', nakol'ko objekt nie je zachytený vo svojom kompletnom tvare. Vel'mi silná oblast' reflexov sa nachádza $\mathrm{v}$ strede tohto objektu a taktiež sa začína prejavovat' $\mathrm{v}$ relatívne plytkých híbkach. Podl'a charakteru pol'a ide s vysokou pravdepodobnostou o prejav dutiny - krypty v podloží kaplnky. Táto anomália sa rozširuje smerom do strán pre väčšie híbky prieniku georadarových meraní, čo by mohlo poukazovat' na prítomnost' klenby danej krypty (horizontálne amplitúdové rezy pretínajú pri väčších híbkach stále väčšiu a väčšiu plochu objektu).

Prítomnost' dutiny (krypty) bola overená aj pomocou neskôr realizovaných mikrogravimetrických meraní - získané hodnoty neúplných Bouguerových anomálií (obr. 7) sa svojimi minimálnymi hodnotami sústred’ujú presne v priestore už spomenutej dominantnej reflexnej anomálie z georadarových meraní.

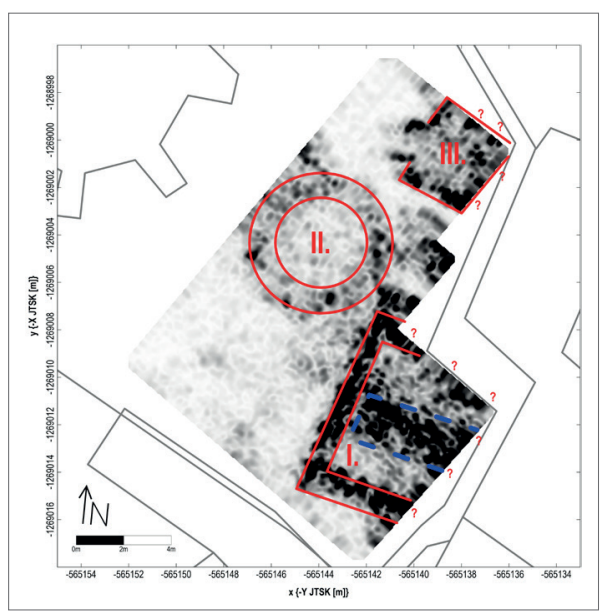

Obr. 8. Interpretovaný horizontálny amplitúdový rez pre híbku prieniku $150 \mathrm{~cm}$ so zaznačením polôh troch hlavných detegovaných objektov (I, II, III). Kružnice a úsečky označujú hranice objektov, vymedzené zvyškami múrov; prerušovaný obdížnik vymedzuje prejav dutiny (krypty).

Abb. 8. Interpretierter horizontaler Amplitudenschnitt für die Eindringtiefe von $150 \mathrm{~cm}$ mit Kennzeichnung der Lage der drei detektierten Hauptobjekte (I, II, III). Die Kreise und Segmente kennzeichnen die durch die Mauerhöhen abgegrenzten Umrisse der Objekte; das gestrichelte Rechteck umgrenzt das Erscheinungsbild eines Hohlraums (Krypta). 
Tab. 1. Zoznam osôb pochovaných v krypte pod Kaplnkou sv. Barbory v dobe po zbúraní kaplnky. Hviezdičkou sú označené pohreby s otáznym zaradením.

Tab. 1. Verzeichnis der in der Krypta unter der St. Barbarakapelle nach dem Abriss der Kapelle beigesetzten Personen. Mit Sternchen gekennzeichnet sind Bestattungen mit problematischer Einordnung.

\begin{tabular}{|c|c|c|c|c|}
\hline Por. č. & $\begin{array}{l}\text { Dátum } \\
\text { pohrebu }\end{array}$ & $\begin{array}{l}\text { Údaje } \\
\text { o zosnulom }\end{array}$ & $\begin{array}{c}\text { Označenie miesta } \\
\text { pohrebu }\end{array}$ & Prameň \\
\hline $1^{*}$ & 20.01.1801 & $\begin{array}{l}\text { de Czanth Ján, major dragúnskeho pluku } \\
\text { Leopolda Toskánskeho, } 86 \text { r. }\end{array}$ & $\begin{array}{l}\text { in caemeterio superiori } \\
\text { ad cryptam }\end{array}$ & ŠABA, ZCM, 1102, 558 \\
\hline 2 & 22.10 .1801 & $\begin{array}{l}\text { Szülessy Eugen, páter rehole piaristov, } \\
\text { vicerektor kolégia vo Svätom Jure, } 72 \mathrm{r} \text {. }\end{array}$ & $\begin{array}{l}\text { ad criptam sub Capella } \\
\text { s. Barbarae }\end{array}$ & ŠABA, ZCM, 1102, 565 \\
\hline 3 & 06.11 .1802 & $\begin{array}{c}\text { Kirchner Anton, plukovník } \\
\text { v t’ažkoodeneckom pluku princa z Nassau, } \\
71 \mathrm{r} \text {. }\end{array}$ & $\begin{array}{l}\text { in crypta ex Sacello } \\
\text { s. Barbarae facta }\end{array}$ & ŠABA, ZCM, 1102, 572 \\
\hline 4 & 03.05 .1803 & Marcel, páter rehole piaristov, $64 \mathrm{r}$. & in crypta s. Barbarae & ŠABA, ZCM, 1102,578 \\
\hline 5 & 12.02 .1805 & $\begin{array}{l}\text { Lihan Pavol, páter rehole piaristov, správca } \\
\text { gramatickej školy, } 68 \mathrm{r} \text {. }\end{array}$ & $\begin{array}{l}\text { in crypta sub Sacello } \\
\text { olim s. Barbarae }\end{array}$ & ŠABA, ZCM, 1103, 3 \\
\hline $6^{*}$ & 15.05 .1809 & $\begin{array}{l}\text { Stetelle Ignác, syn senátora, pivovarník, } \\
23 \mathrm{r} .\end{array}$ & $\begin{array}{l}\text { in crypta statim ad } \\
\text { ingressum coemeterii } \\
\text { a dextris }\end{array}$ & ŠABA, ZCM, 1103, 52 \\
\hline $7 *$ & 13.12.1809 & $\begin{array}{l}\text { Szaibely Ondrej, senátor, kostolný } \\
\text { inšpektor, } 61 \mathrm{r} \text {. }\end{array}$ & $\begin{array}{l}\text { in crypta statim penes } \\
\text { portam }\end{array}$ & ŠABA, ZCM, 1103, 61 \\
\hline 8 & 14.09.1811 & $\begin{array}{c}\text { Tsikely Štefan, páter rehole piaristov, } \\
\text { profesor, } 29 \mathrm{r} \text {. }\end{array}$ & in crypta s. Barbarae & ŠABA, ZCM, 1103, 76 \\
\hline 9 & 15.03.1812 & $\begin{array}{l}\text { Geraldovich Hieroným, páter rehole } \\
\text { piaristov, slovenský kazatel', } 63 \mathrm{r} \text {. }\end{array}$ & in crypta s. Barbarae & ŠABA, ZCM, 1103, 84 \\
\hline 10 & 24.08 .1815 & Maar Alžbeta, manželka senátora, 66 r. & in crypta s. Barbarae & ŠABA, ZCM, 1103, 102 \\
\hline 11 & 14.09.1815 & Zellinger Anna, vdova po mešt’anovi, 60 r. & in crypta s. Barbarae & ŠABA, ZCM, 1103, 102 \\
\hline 12 & 02.02 .1816 & a Fialla Karolína, dcéra plukovníka, 18 r. & in crypta s. Barbarae & ŠABA, ZCM, 1103, 105 \\
\hline 13 & 23.04 .1816 & $\begin{array}{l}\text { Prunner Juraj, kapitán t’ažkoodeneckého } \\
\text { pluku vojvodu Františka Milánskeho, } 42 \text { r. }\end{array}$ & in crypta s. Barbarae & ŠABA, ZCM, 1103, 106 \\
\hline $14 *$ & 05.05 .1816 & a Fiala Terézia, dcéra plukovníka, 20 r. & $\begin{array}{l}\text { in cripta penes } \\
\text { s. Barbarae capellam }\end{array}$ & ŠABA, ZCM, 1103, 106 \\
\hline $15^{*}$ & 13.05.1816 & $\begin{array}{c}\text { a Brodtrager Veronika, manželka kapitána } \\
\text { t'ažkoodeneckého pluku vojvodu Františka } \\
\text { Milánskeho, } 45 \text { r. }\end{array}$ & $\begin{array}{l}\text { in cripta penes } \\
\text { s. Barbarae capellam }\end{array}$ & ŠABA, ZCM, 1103, 106 \\
\hline 16 & 07.12 .1817 & Doraszil Matúš, učitel’ 2. triedy, 62 r. & in crypta s. Barbarae & ŠABA, ZCM, 1103, 114 \\
\hline $17^{*}$ & 25.05 .1827 & $\begin{array}{c}\text { Pritz Felix, páter rehole piaristov, profesor } \\
\text { a nemecký kazatel', } 26 \text { r. }\end{array}$ & in crypta anteriore & ŠABA, ZCM, 1103, 168 \\
\hline
\end{tabular}

Amplitúda tejto negatívnej anomálie dosahuje úroveň cca $-0,035 \mathrm{mGal}$, čo môže zodpovedat' prítomnosti nezavalenej dutiny s objemom rádovo prvých desiatok kubických metrov.

Meraniami zistená lokalizácia pozostatkov stavby zodpovedá jej umiestneniu zistenému z grafických prameňov, t. j. z veduty z roku 1736 a mapy z roku 1769. Pri porovnaní mapy z roku 1769 a reálneho stavu sa ukazujú rozdiely v rozmiestnení objektov. Rozdiely sú spôsobené najmä tým, že os farského kostola je na mape nesprávne orientovaná s odchýlkou viac ako $15^{\circ}$ smerom na juh oproti skutočnosti. Po pomyselnom pootočení osi do správnej polohy môžeme objekt, ktorý je na mape označený ako „smrtná kaplnka“ (Todten-Capelle, značená písmenom c), stotožnit’s objektom I (Kaplnka sv. Barbory). Tomu zodpovedá aj poloha oboch objektov (,c“" a objekt I) hned’ pri vstupe do areálu kostola. Neoznačený objekt vybiehajúci z hradieb môžeme potom stotožnit's karnerom skúmaným v rokoch 2004-2005 (porov. mapku v práci Budaj-Nagy 2005). 
Nameraná vnútorná šírka objektu (približne 5,7 m) zodpovedá údaju z vizitácie z roku 1781, avšak len za predpokladu, že text vizitácie uvádza vnútorné rozmery stavby. Ak by text uvádzal vonkajšie rozmery, potom je potrebné meraním zistenú odchýlku adekvátne preniest' aj na dížku stavby, ktorá by namiesto v prameni zaznamenaných 10,45 m mohla byt' až 13,75 m. Merania zároveň potvrdili zachovanie podzemnej časti stavby (krypty), ktorá bola aj po zániku nadzemnej časti používaná na pochovávanie.

\section{Objekt II}

$\mathrm{Na}$ viacerých horizontálnych georadarových rezoch (obr. 6) sa prejavil vel'mi zaujímavý objekt kruhového tvaru, ktorý sa nachádza bližšie ku kostolu (obr. 8). Vnútorný priemer tohto objektu je približne 4,5 $\mathrm{m}$ a vonkajší približne $6,5 \mathrm{~m}$. Začína sa prejavovat' približne od híbkovej úrovne $125 \mathrm{~cm}$ a prejavy pokračujú do híbky $275 \mathrm{~cm}$. Vnútorný priestor tohto objektu nevykazuje výrazné reflexné anomálie (v porovnaní s opísaným objektom I). Z uvedeného je možné konštatovat', že vo vnútornom priestore tohto objektu sa nenachádzajú d’alšie stavebné prvky alebo dutiny (krypta).

Prítomnost' tejto stavby v blízkosti kostola nezaznamenala ani vizitácia z roku 1612 (spomína kostol a kaplnku), ani urbár z roku 1618 (spomína kostol, kaplnku a zvonicu), ani vizitácia z roku 1634 (rovnako spomína kostol, kaplnku a zvonicu). Jej existenciu nezaznamenal ani žiaden z vyššie citovaných mladších prameňov, nie je zakreslená na spomenutej vedute a ani na mape mesta. Pri jej pomerne vel'kých rozmeroch to nemôže byt' pripísané nezáujmu alebo nevšímavosti autorov týchto prameňov. Je treba skôr predpokladat', že stavba v čase vzniku prameňov už neexistovala a musela byt' dokonca zaniknutá do takej miery, že jej zvyšky neboli v priestore vôbec viditel'né. Musela teda zaniknút' najneskôr v 16. storočí. Istý čas mohla stát'v areáli súčasne s Kostolom sv. Juraja a s Kaplnkou sv. Barbory, pretože všetky tri objekty vzájomne rešpektujú svoje pôdorysy. S ohl'adom na pomerne malý priestor areálu a zároveň nezvyčajný pôdorysný tvar objektu by mohlo íst' o predchodkyňu niektorej z uvedených dvoch stavieb (kostol alebo kaplnka), ktorá bola po dokončení svojho nástupcu zbúraná ako nepotrebná.

\section{Objekt III}

Ďalšou dominantnou anomálnou črtou, ktorá sa prejavuje na viacerých horizontálnych georadarových rezoch (obr. 5 a 6), je objekt približne obdĺžnikového tvaru v severnej časti preskúmanej plochy (obr. 8). Jeho rozmery sú približne $3 \times 3 \mathrm{~m}$, pričom je ale dôležité spomenút', že jeho ohraničenie zo severnej a východnej strany nie je úplne jednoznačne definované, nakol'ko tieto časti plochy nemohli byt' úplne pokryté georadarovými meraniami (na okrajoch plochy sa nachádzal múr areálu kostola). Začína sa prejavovat' relatívne plytko - už cca od híbky $30 \mathrm{~cm}$ a prejavy pokračujú smerom do híbky, spodné ohraničenie sa však nedá spol'ahlivo určit'. Aj v tomto prípade je možné konštatovat', že vnútorný priestor objektu nevykazuje výrazné reflexné anomálie (v porovnaní s opísaným objektom I). Takže aj tu je možné konštatovat', že vo vnútornom priestore tohto objektu sa nenachádzajú dutiny (krypty). Na híbkovej úrovni $50 \mathrm{~cm}$ (obr. 5) sa nachádza prejav líniovitého reflexu, čo by mohlo svedčit’ o prítomnosti určitých vnútorných stavebných prvkov v objekte.

Ani tento objekt sa na základe zhromaždených archívnych prameňov nepodarilo identifikovat'. Pri jeho pomerne malých rozmeroch, jednoduchom pôdoryse a absencii dutiny (krypty) je zaujímavá najmä relatívne vel'ká híbka, do ktorej objekt siaha.

\section{Menšie objekty}

Na základe posúdenia výsledkov z georadarových meraní z niektorých plytších úrovní (obr. 5) sme vyčlenili polohy d’alších piatich menších objektov (obr. 9). S ohl'adom na charakter získaných 
georadarových údajov nie je možné s istotou interpretovat', či ide o zvyšky múrov alebo o malé dutiny, resp. vyplnené výkopy (hroby). Objekty č. 1, 2 a 3 vykazujú relatívne silné amplitúdy, čiže by mohlo íst' o zvyšky kompaktných múrov alebo o menšie dutiny. Objekty č. 4 a 5 vykazujú pomerne pravidelný obdížnikový tvar (obr. 9), takže by sa mohlo jednat' o zvyšky múrov ohraničujúcich individuálne hroby. Objekt č. 5 zasahuje do objektu III z obr. 8 a narúša tak jeho celistvost'. Mikrogravimetrický prieskum nebol na miestach objektov č. 1 až 3 zatial' realizovaný a kvôli ich malým rozmerom by pravdepodobne ani nepriniesol očakávané výsledky (ako aj d’alšie geofyzikálne metódy, ako rezistívna tomografia a plytká refrakčná seizmika). Tieto objekty bude pravdepodobne možné overit' iba pomocou archeologického výskumu.

Prítomnost' takýchto objektov nie je v skúmanom priestore prekvapujúca, ked’že na cintoríne okolo presbytéria kostola boli často pochovávané významné osobnosti mesta, ako kňazi, predstavitelia samosprávy (napr. richtári), miestni šlachtici a pod. Viacerí z nich pritom boli pochovaní do vymurovaných hrobov, resp. do drobných krýpt. Dosvedčuje to napríklad záznam o pohrebe šlachtica Jozefa Jablanczyho († 1840), ktorý bol prísediacim súdnej tabule, zastupujúcim podžupanom a generálnym perceptorom Bratislavskej stolice. Ako miesto jeho pochovania je uvedená „murovaná jama pri kostole“ (in muratu fossa ad ecclesiam; ŠABA, ZCM, 1103, 232). Jablanczyovská hrobka (sepulcrum) sa spomína aj v rokoch 1864 a 1866 (ŠABA, ZCM, 1105, 107; 1106, 2). Takýchto drobných krýpt alebo hrobiek mohlo byt' okolo kostola rozmiestnených pomerne vel'a. Pri pohrebe Terézie, vdovy po pivovarníkovi Antonovi Schildknechtovi, sa v roku 1810 uvádza, že bola pochovaná na vnútornom cintoríne (t. j. pri kostole, v priestore obohnanom hradbou) „,vedl'a strednej krypty“ (penes cryptam mediam; ŠABA, ZCM, 1103, 70).

\section{Záver}

Interdisciplinárny výskum juhovýchodnej časti opevneného areálu Kostola sv. Juraja vo Svätom Jure priniesol viacero nových a prekvapivých zistení. V prvom rade bola jednoznačne určená poloha zaniknutej stredovekej kaplnky zasvätenej sv. Barbore, ktorá až do konca 18. storočia dotvárala podobu náboženského centra mesta. $Z$ jej pôdorysu sa zachovala celá šírka a približne jedna polovica z predpokladanej dížky. Ako dodnes zachovaná sa potvrdila krypta pod týmto objektom. Neočakávaným zistením bola identifikácia d’alších dvoch zaniknutých objektov v tomto priestore. Z nich sa ako obzvlášt' zaujímavý javí objekt kruhového pôdorysu (tu označený ako objekt II), ktorý by mohol prispiet' k objasneniu najstarších dejín stavebného vývoja areálu. Kým totiž posledný pamiatkový výskum identifikoval v Kostole sv. Juraja románske jadro rámcovo datované do prvej polovice 13. storočia (Sabadošová 2012, 164), existencia sakrálnej stavby sa v lokalite predpokladá už na prelome 11. a 12. storočia (Turcsány 2009, 32). Ďalšie prehĺbenie predstavených záverov bude možné len prostredníctvom archeologického výskumu. 
Prezentovaná štúdia bola realizovaná v rámci Grantu UK č. UK/404/2018 „Historicko-geofyzikálny výskum zaniknutej kaplnky vo Svätom Jure“ a čiastočne bola podporená aj projektom VEGA 2/0100/20. Autori príspevku by zároveň radi vyjadrili vd’aku Jozefovi Bódimu za pomoc pri realizácii mikrogravimetrických meraní na študovanej lokalite.

\section{Pramene a literatúra}

AFSJ, Viz 1731: Archív Rímskokatolíckej cirkvi, farnosti Svätý Jur, Visitatio ecclesiae liberae regiaeque civitatis Sancto Georgiensis anno 1731 die 19 maii et subsequentibus peracta (bez sign.).

AFSJ, Viz 1756: Archív Rímskokatolíckej cirkvi, farnosti Svätý Jur, Visitatio ecclesiae liberae regiae civitatis Sancto Georgiensis anno 1756 die 18 et sequenti junii peracta (bez sign.).

AFSJ, Viz 1781: Archív Rímskokatolíckej cirkvi, farnosti Svätý Jur, Visitatio Batthianiana parochiae Sancti Georgii die 21 septembris anno 1781 in districtu Baziniensi (bez sign.).

AFSJ, Viz 1823: Archív Rímskokatolíckej cirkvi, farnosti Svätý Jur, Decretum visitationis canonicae in parochia liberae regiaeque civitatis Sancto Georgiensis Anno 1823 peracta (bez sign.).

APÚ, POS: Archív Pamiatkového úradu Slovenskej republiky, archívny fond Pamiatkové orgány na Slovensku, inv. č. 435/25 - Jur pri Bratislave - Kostol r. k. farský, pol. č. 93, spis č. 880/1921.

BEKE, M., 1994: Pázmány Péter egyházlátogatási jegyzőkönyvei 1616-1637. Strigonium Antiquum 3. Budapest.

BEL, M., 1736: Notitia Hungariae novae historico geographica divisa in partes quatuor... Tomus secundus. Viedeň.

BUDAJ, M.-NAGY, P., 2005: Poklad mincí zo 17. storočia a výskum karnera vo Svätom Jure, ZbSNM 99, Archeológia 15, 155-208.

ELTEK, Ab 28: Eötvös Loránd Tudományegyetem Könyvtár, zbierka Manuscripta, Ab. Egyháztörténelem, Szerzetek, č. 28 - Visitatio sub archidiaconatu praepositurae Posoniensis parochiarum, seu in comitatu Posoniensi existentium, anno 1673 14. sept. instituta.

ELTEK, Ab 30: Eötvös Loránd Tudományegyetem Könyvtár, zbierka Manuscripta, Ab. Egyháztörténelem, Szerzetek, č. 30 - Visitatio districtus Baziniensis per me Ottonem Joannem Baptistam comitem a Volkra praepositum, archidiaconum et plebanum posoniensem facta.

GRÓSZ, A., s. d.: Geschichte der Stadt und der evangelischen Kirchengemeinde A. C. der königl. Freistadt Sct. Georgen. II. Auflage. Galanta.

HINZE, W. J.-VON FRIESE, R. R. B.-SAAD, A. H., 2013: Gravity and Magnetic Exploration. Principles, Practices and Applications. Cambridge.

LEŠKA, J., 1882: K starožitnému čtení, Korouhev na Sionu 5, 202-203.

LUZ, R., 2017: Náboženský život mestečka Svätý Jur v rokoch 1514-1628. In: Doležalová, M.-Pavlíková, L. et al., „Tu stojím, inak nemôžem...": Reformácia od počiatkov do súčasnosti. Bratislava.

-2018: Stratené epigrafické pamiatky Kostola sv. Juraja vo Svätom Jure, Pamiatky a múzeá 67, 44-47.

MNLOL, P 1391: Magyar Nemzeti Levéltár Országos Levéltára, archívny fond P 1391 Jeszenák család lajstromozott iratai, 6. csomó, Fasc. XLVI, No. 6 - Urbarium Anno 1618.

NA, MŠ: Národní archiv, archívny fond Ministerstvo školství Praha, sign. 30 - památky, karton č. 3160 , Svätý Jur, spis č. 213/1921.

PANISOVA, J. et al., 2016: Panisova, J.-Murín, I.-Pašteka, R.-Haličková, J.-Brunčák, P.-Pohánka, V.Papčo, J.-Milo, P., Geophysical fingerprints of shallow cultural structures from microgravity and GPR measurements in the Church of St. George, Svätý Jur, Slovakia, Journal of Applied Geophysics 127, č. 1, 102-111.

PAŠTEKA, R. et al., 2019: Pašteka, R.-Kušnirák, D.-Wilken, D.-Putiška, R.-Papčo, J.-Godová, D.-Zvara, I.-Nogová, E.-Ondrášová, L., Effective combination of microgravimetry and geoelectrical methods in the detection of subsurface cavities in archaeological prospection - selected case-studies from Slovakia, Contributions to Geophysics and Geodesy 49, 479-496.

PAVELEK, J., 1942: Kronika svätojurskej rímskokatolíckej farnosti. Vybrané časti z latinských originálov preložil PhDr. Juraj Pavelek. Rkp. v súkromnom vlastníctve potomkov autora. 
PLE, Lib 17a: Prímási Levéltár Esztergom, Egyházi Levéltár, Visitationes canonicae, Liber 17a - Visitatio canonica parochiarum sub archidiaconatu Posoniensi existentium... peracta 1714.

PLE, Lib 89: Prímási Levéltár Esztergom, Egyházi Levéltár, Visitationes canonicae, Liber 89 - Conscriptio parochiarum districtus Baziniensis... 1761.

SABADOŠOVÁ, E., 2010: Rímskokatolícky farský kostol sv. Juraja vo Svätom Jure. Architektonicko-historický a umelecko-historický výskum stien v interiéri hlavnej a bočnej lode. Rkp. uložený v Archíve Rímskokatolíckej cirkvi, farnosti Svätý Jur.

- 2012: Svätý Jur, Kostol sv. Juraja, Horné predmestie 18. In: Ročenka pamiatkových výskumov 2010, 163166. Bratislava.

SANDMEIER, K. J., 2019: ReflexW Vers. 9, Manual. SandmeierGeo, Karlsruhe, Manuscript, online, accessed 2019-11-18. Dostupné z: https:/www.sandmeier-geo.de/down load.html.

ŠABA, ZCM, 1090: Štátny archív v Bratislave, Zbierka cirkevných matrík, inv. č. 1090 - Svätý Jur, r. k., Matrika pokrstených, sobášených a pochovaných 1700-1716.

ŠABA, ZCM, 1102: Štátny archív v Bratislave, Zbierka cirkevných matrík, inv. č. 1102 - Svätý Jur, r. k., Matrika pochovaných 1739-1804.

ŠABA, ZCM, 1103: Štátny archív v Bratislave, Zbierka cirkevných matrík, inv. č. 1090 - Svätý Jur, r. k., Matrika pochovaných 1805-1843.

ŠABA, ZCM, 1105: Štátny archív v Bratislave, Zbierka cirkevných matrík, inv. č. 1090 - Svätý Jur, r. k., Matrika pochovaných 1852-1865.

ŠABA, ZCM, 1106: Štátny archív v Bratislave, Zbierka cirkevných matrík, inv. č. 1090 - Svätý Jur, r. k., Matrika pochovaných 1866-1893.

ŠABA-Mo, ZMP: Štátny archív v Bratislave, pracovisko Archív Modra, Zbierka máp a plánov, sign. J-1 Mapa mesta Svätý Jur z roku 1769.

TURCSÁNY, J. et al., 2009: Svätý Jur 1209-2009. Dejiny písané vínom. Svätý Jur.

\section{Zusammenfassung}

\section{Untergegangene Bauten im Areal der Pfarrkirche in Svätý Jur (Ergebnisse der geophysikalischen Untersuchung und Archivforschung)}

Das Areal der gotischen Kirche St. Georg in Svätý Jur war bislang Gegenstand von zwei in den Jahren 1921 und 2004-2005 durchgeführten archäologischen Teilgrabungen. Anstoß dazu gaben Zufallsfunde von Baukonstruktionen, die bei Bauarbeiten entdeckt worden waren. In den Jahren 2018 und 2019 wurde eine geophysikalische Untersuchung und Archivforschung durchgeführt, deren Ziel es war, Überreste von der mittelalterlichen St. Barbarakapelle zu lokalisieren. Die Existenz des kleineren Sakralbaus in diesem Areal ist in zwei Quellen belegt: durch eine Stadtansicht der Stadt St. Georgen (Svätý Jur) aus dem Jahr 1736 (südlich vom Presbyterium der Kirche zeigt sie einen Bau mit offenbar quadratischem Grundriss, der ungefähr in südöstlicher Richtung außen an die Umfriedungsmauer des Areals anschließt), und durch eine Karte der Stadt St. Georgen aus dem Jahr 1769 (im Areal der Kirche wird eine „Todten-Capelle“ angezeigt). Beide Quellen lokalisieren den Bau im Süden oder Südosten des Areals in der Nähe der Umfriedungsmauer und neben der zur Kirche führenden Treppe. Auf dieser Grundlage wurde die Fläche zur Durchführung der geophysikalischen Untersuchung ausgewählt. Das Areal wurde in seinem südöstlichen Teil mit der Georadar-Methode untersucht, und ein ausgewählter Teil der Fläche auch mit dem Verfahren der Mikrogravimetrie. Im Falle der Georadarmessung wurde eine Fläche von unregelmäßiger Form mit einer Größe von ca. $175 \mathrm{~m}^{2}$ gemessen. Output der Georadarmethode waren Karten mit den Amplitudenwerten in den gewählten Höhenniveaus für die gewählten Tiefen. Auf diesen Karten wurden die detektierten Objekte mit dunkleren Farbtönen hervorgehoben. Im Falle der mikrogravimetrischen Messungen wurde eine kleinere Fläche gemessen, die anhand der Ergebnisse der Georadarmessung über dem detektierten 
Objekt I bestimmt wurde. Ergebnis der Untersuchung ist die Identifizierung der Überreste von drei selbständigen Objekten.

Die Ergebnisse zu Objekt I (St. Barbarakapelle): Bei der Archivforschung wurden mehrere Quellen zu dem Bau ausfindig gemacht. Die älteste Erwähnung befindet sich in Rechnungen aus dem Jahr 1580 (Ausgaben für Reparaturarbeiten). Das Urbar aus dem Jahr 1618 beschreibt eine kleinere Kirche mit Sanktuarium. Laut einer kanonischen Visitation aus dem Jahr 1634 war die Kapelle auf dem Friedhof immer geschlossen und leer. Eine Visitation aus dem Jahr 1714 erwähnt erstmals eine Krypta unter dem Bau. In der Visitation aus dem Jahr 1731 befindet sich die Angabe, dass die Kapelle seit 1491 leerstand. Die Kapelle wird letztmalig in einer Visitation aus dem Jahre 1781 erwähnt. Danach war sie fünfeinhalb Klafter lang, drei Klafter breit und ebenfalls drei Klafter hoch (ungefähr 10,45 × 5,7 × 5,7 m), war aus Stein in gotischem Stil erbaut und im Innern gepflastert. Das Dach hatte eine Ziegeleindeckung. Die Krypta unter dem Bau wurde als Beinhaus genutzt. Die Kapelle wurde im Jahr 1798 abgerissen, zwei Jahre später wurde das Beinhaus geräumt und eine Krypta an seiner Stelle eingerichtet. Bis zum Jahr 1817 sind mindestens 11 Bestattungen in ihr belegt. Anhand der Ergebnisse der Georadarmessung kann der Verlauf eines Teils der Fundamentüberreste des Objektes ausgemacht werden. Sie sind durch die dominanten Amplituden der Reflexionen bereits ab einem Tiefenniveau von $30 \mathrm{~cm}$ erkennbar. Diese Reflexionen geben eine nicht ganz rechteckige Form wieder (ein Teil des Objektes war zerstört). Die erhalten gebliebene Seite des Objektes hat horizontal eine Innenabmessung von ungefähr 5,7 m, die Außenabmessung beträgt ungefähr 7,5 m. Die zweite Seite des Objektes wurde nicht in ihrer kompletten Gestalt erfasst. Ein sehr starker Bereich an Reflexionen in der Mitte des Objektes beginnt in relativ flachen Tiefen in Erscheinung zu treten, dem Charakter des Feldes nach zu urteilen, handelt es sich dabei wahrscheinlich um das Erscheinungsbild eines Hohlraums - der Krypta. Das Vorhandensein eines Hohlraums (Krypta) wurde auch durch die später durchgeführte mikrogravimetrische Messung verifiziert - die gewonnenen Werte unvollständiger Bouguer-Anomalien konzentrieren sich mit ihren Mindestwerten genau in dem Bereich der bereits erwähnten dominanten Reflexionsanomalien der Georadarmessung.

Die Ergebnisse zu Objekt II: Die horizontalen Georadarschnitte zeigen ein Objekt von runder Form. Der Innendurchmesser des Objektes beträgt ungefähr 4,5 m und der Außendurchmesser ungefähr 6,5 m. Es beginnt ungefähr ab einem Tiefenniveau von $125 \mathrm{~cm}$ in Erscheinung $\mathrm{zu}$ treten und reicht bis zu einer Tiefe von $275 \mathrm{~cm}$. Der Innenraum des Objektes zeigt keine ausgeprägten Reflexionsanomalien, und offenbar befinden sich in ihm keine weiteren baulichen Elemente oder Hohlräume (Krypta). Die Existenz des Baus ist in keiner Archivquelle verzeichnet. Es ist anzunehmen, dass der Bau zur Entstehungszeit der Quellen bereits nicht mehr existiert hat und in diesem Bereich auch keine Überreste von ihm mehr sichtbar waren. Er muss spätestens im 16. Jahrhundert untergegangen sein. Für einen gewissen Zeitraum konnte er zur gleichen Zeit wie die St. Georgskirche und die St. Barbarakapelle existiert haben, da alle drei Objekte ihre Grundrisse gegenseitig respektieren.

Die Ergebnisse zu Objekt III: Ein weiteres dominantes anomales Muster, das auf mehreren horizontalen Georadarschnitten in Erscheinung tritt, ist ein Objekt von annähernd rechteckiger Form im nördlichen Teil der Fläche. Seine Abmessungen betragen ungefähr $3 \times 3 \mathrm{~m}$ (die Abgrenzung von der Nord- und Ostseite ist nicht ganz eindeutig definiert - Teile der Fläche wurden von den Messungen wegen der Mauern des Kirchenareals nicht abgedeckt). Es beginnt relativ flach in Erscheinung zu treten - bereits ab einer Tiefe von ca. $30 \mathrm{~cm}$. Auch der Innenraum dieses Objektes weist keine ausgeprägten Reflexionsanomalien auf - im Innenraum befinden sich keine Hohlräume (Krypten). Im Tiefenniveau von $50 \mathrm{~cm}$ befindet sich das Erscheinungsbild einer linienförmigen Reflexion, was auf das Vorhandensein von Bauelementen im Innenraum hindeuten könnte. Auch dieses Objekt konnte in den Archivquellen nicht identifiziert werden.

Die Ergebnisse zu kleineren Objekten: Anhand der Ergebnisse der Georadarmessung von einigen flacheren Höhenniveaus haben wir die Lage von fünf kleineren Objekten ausgemacht. Die Objekte Nr. 1, 2 und 3 weisen relativ starke Amplituden auf, es kann sich dabei also um die 
Überreste von kompakten Mauern oder um kleinere Hohlräume handeln. Die Objekte Nr. 4 und 5 weisen eine relativ regelmäßige rechteckige Form auf, sodass es sich um die Reste von Mauern handeln könnte, die Einzelgräber umgrenzen. Objekt Nr. 5 reicht bis in Objekt III hinein und stört dessen Geschlossenheit.

Die hier vorgelegte Studie wurde im Rahmen des Förderprogramms UK Nr. UK/404/2018 „Historisch-geophysikalische Untersuchung der untergegangenen Kapelle in Svätý Jur“ durchgeführt und teilweise auch von dem Projekt VEGA 2/0100/20 gefördert. Die Verfasser des Beitrags möchten gleichzeitig auch Herrn Josef Bódim für dessen Hilfe bei der Durchführung der mikrogravimetrischen Messungen an der untersuchten Fundstelle ihren Dank aus aussprechen.

Mgr. Rastislav Luz, PhD., Ministerstvo vnútra Slovenskej republiky, Slovenský národný archív, Drotárska cesta 52, 84005 Bratislava, Slovenská republika, rastislav.luz@gmail.com

prof. RNDr. Roman Pašteka, PhD., Katedra aplikovanej a environmentálnej geofyziky Prírodovedeckej fakulty Univerzity Komenského, Ilkovičova 6, 84215 Bratislava, Slovenská republika, roman.pasteka@uniba.sk

Mgr. David Kušnirák, PhD., Katedra aplikovanej a environmentálnej geofyziky Prírodovedeckej fakulty Univerzity Komenského, Ilkovičova 6,842 15 Bratislava, Slovenská republika, david.kusnirak@uniba.sk

Mgr. Barbora Šimonová, PhD., Katedra aplikovanej a environmentálnej geofyziky Prírodovedeckej fakulty Univerzity Komenského, Ilkovičova 6, 84215 Bratislava, Slovenská republika, barbora.simonova@gmail.com 
